\title{
PERSONAL INFORMATION \\ AS A HISTORICAL SOURCE USING THE EXAMPLE OF THE ESTONIAN AND OTHER BALTIC DIASPORAS IN KAZAKHSTAN ${ }^{1}$
}

\author{
Mariya Oinas
}

According to the latest census (2009), sixteen million people live in the Republic of Kazakhstan. Forty percent of the population is non-Kazakh, including representatives of almost 130 nationalities and ethnic groups. The formation of the multinational population of Kazakhstan has a complex two-century history. Up to the eighteenth century, Kazakhs constituted most of the inhabitants of the Kazakh Khanate. With the incorporation of Kazakhstan into the Russian Empire, the resettlement of Slavic peoples into the steppe regions began, the influx consisting of mostly peasants and Cossacks. From the first half of the eighteenth century, fortifications and lines of defence were built and settled by serfs. The tsarist state also used Kazakhstan as a place of political exile. The main influx of migration was related to the resettlement policy of the Russian Prime Minister P. Stolypin in the early twentieth century, which was supposed to solve the economic, social and demographic problems of the Russian Empire through the development of new lands. According to some estimates, over one million people from the European regions of the empire immigrated to Kazakhstan in the pre-revolutionary period. ${ }^{2}$

The Soviet government also contributed to the multinational character of the population of Kazakhstan through massive forced migrations. Shortly after the October Revolution, intellectuals, clergy and aristocrats

\footnotetext{
1 The research for this article was conducted with the support from the European Regional Development Fund.

2 Nacionalnyj sostav, veroispovedanie i vladenie jazykami v Respublike Kazahstan (Astana: Agentstvo Respubliki Kazahstan po statistike, 2010), 4, ed. by Alihan Smailov, Itogi Nacionalnoy perepisi naseleniya Respubliki Kazahstan 2009g. (Astana, 2010) $<$ https://stat.gov.kz/census/national/2009/general > [accessed 25 May 2020]; Nailya Bekmahanova, Mnogonatsionalnoye naseleniye Kazakhstana i Kirgizii v epokhu kapitalizma (6o-ye gody XIX v. - 1917 g.) (Moscow: Nauka, 1986).
} 
were exiled to Kazakhstan, Siberia and the Urals. During the years of collectivisation, Kazakhstan became a place of exile for dispossessed peasants. Stalin's deportations forcibly resettled Koreans, Volga Germans, Poles, Chechens, Ingush, Kurds, Meskhetian Turks, Karelians, Finns, Latvians, Lithuanians and Estonians, as well as many other nationalities, in Kazakhstan. The last wave of mass migration is associated with the Virgin Lands Campaign from 1954 to 1962.

There is a growing body of literature that recognises the importance of studying the history of national minorities in Kazakhstan (G. Kim, G. Kan, L. Burgart, G. Mendikulova, F. Razhepaeva, S. Mashimbayev, L. Isova, etc.). ${ }^{3}$ These studies focus mainly on the history of Koreans, Chechens, Germans, Tatars, and Poles in Kazakhstan. Research on the topic of forced migration and national minorities in the Russian Empire and the Soviet Union has gained prominence since the 1980s. The 1990 os and the beginning of the 2ooos saw an upsurge in historical publications on this topic (N. Bekmahanova, A. Alekseyenko, N. Alekseyenko, M. Kozybaeyev, M. Kalybekova, etc.). ${ }^{4}$

Up to now, far too little attention has been paid to the history of the formation of certain diasporas, among them the Estonian, Latvian, and Lithuanian diasporas of Kazakhstan. The 2009 census recorded the residence of about 7,000 representatives of these nationalities in the republic, which is less than $0.1 \%$ of the population. ${ }^{5}$ This is one of the key reasons for the dearth of knowledge about their history. One further reason is the lack of sources. Since the number of migrants from the Baltic countries was always small in comparison to other nationalities (Russians, Ukrainians, Belarusians, Germans, Poles, etc.), their statistics are often not reflected in consolidated statistical references, archival materials, and publications. Thus, during the peasant resettlement of the late nineteenth to early twentieth

\footnotetext{
3 German Kim, Koreytsy Kazakhstana (Astana, 2016); Georgiy Kan, Istoriya koreytsev $v$ Kazakhstane (Almaty: Gylym, 1995); Lyudmila Burgart, Nemetskoye naseleniye v Vostochnom Kazakhstane v1941-1956 gg. (Ust-Kamenogorsk: Altay-Vita, 2001); Gulnara Mendikulova, Istoricheskiye sudby kazakhskoy diaspory: proiskhozhdeniye i razvitiye (Almaty: Gylym, 1997); Fauziya Razhepayeva, 'Tatary Kazakhstana v 1970-1999 gg.' (unpublished doctoral thesis, Sarsen Amanzholov East Kazakhstan State University, 2008); Serik Mashimbayev and Laura Isova, Problema Istorii Polskikh Pereselentsev $v$ Kazakhstane (1936-1946 Gg.) (Almaty, 20oo).

4 Bekmahanova, Mnogonatsionalnoye naseleniye Kazakhstana i Kirgizii v èpohu kapitalizma: (6o-e gody XIX v. - 1917 g.); Abish Kekilbaev, Deportirovannyye v Kazakhstan narody: vremya i sudby (Almaty: Arys, 1998); Manara Kalybekova, Istoriya Deportirovannykh Narodov Kazakhstana (1937-1956 Gg.) (Almaty: 2008); Etnosy Kazakhstana: istorikodemograficheskiy spravochnik, ed. by Aleksandr Alekseyenko (Astana: Yelorda, 2001).

5 Smailov, Nacionalnyj sostav. Itogi perepisi 2009 g.
} 
centuries, Latvians and Estonians were mentioned only in the context of the 'German population'. Meanwhile, in the Stalinist deportations, the numbers of Estonians, Latvians and Lithuanians were also obscured by the more numerous masses of Germans, Poles and Belarusians.

The history of the Estonian, Latvian, and Lithuanian diasporas in Kazakhstan is of additional interest because it is an important aspect of the history of all these countries. On the one hand, it is important to know why residents of the Baltic states left or were forcibly resettled and where they went. On the other hand, even small diasporas are an integral part of the entire population of Kazakhstan. They have their own history, which, like pieces of a puzzle, contributes to the overall picture of the country's twentieth-century history.

The purpose of this paper is to show how the Estonian diaspora took shape in Kazakhstan in comparison with other Baltic diasporas (Latvians and Lithuanians). Even though the Baltic countries had similar destinies during a certain period of history (being part of the Russian Empire, a period of independence, and incorporation into the Soviet Union), their emigration to Kazakhstan had a different nature. Hence, the Estonian diaspora of Kazakhstan was formed in the late $19^{\text {th }}$ and early $20^{\text {th }}$ centuries during the peasant colonisation of Central Asia. Estonians established several settlements in the Akmola and Semipalatinsk provinces. The Latvian diaspora also originates in this period, but Latvians did not establish separate colonies. They lived in nationally mixed settlements (German, Russian and Estonian), as well as in the cities of the Steppe Territory. At the same time, the number of peasant immigrants from the Lithuanian province was insignificant and did not form the foundation for an emerging diaspora. Lithuanians were forcibly relocated to Kazakhstan during the deportations of the 1940s. As a result, their number in the republic increased by eleven thousand people, and the Lithuanian diaspora became the largest of the Baltic diasporas in Kazakhstan. It continues to maintain this position at present.

As mentioned above, one of the main obstacles to studying these diasporas is the small source base, as well as its fragmentation. There are no separate files for Estonians, Latvians, or Lithuanians in the archives of Kazakhstan. In Kazakhstani research, scholars do not separate them, and often include them in the categories of 'others' or lump them together with other nationalities. Researchers of the Baltic states have not treated Baltic diasporas in Kazakhstan in much detail. They have instead focused on voluntary and forced migrations to the territory of Russia. Also, the 
geographical remoteness of empirical archival material complicates the study of this topic for Latvian, Lithuanian and Estonian historians.

In the light of these difficulties, I have worked for ten years on creating a data collection of personal data on all the representatives of the Estonian, Latvian and Lithuanian nationalities who have ever lived in the territory of the Republic of Kazakhstan. Today, the data collection includes more than one thousand people.

This article is the first attempt at a comprehensive analysis of available biographical data. The first section of this paper will provide a description of the methodology used to collect and analyse personal data, as well as analysis of the main groups of sources. Within the framework of one article, it is impossible to comprehensively cover the history of Estonian settlements over the course of a century (1893-1999). Therefore, the second section dwells on the issue of the emergence of Estonian settlements in Kazakhstan based on an analysis of personal data. The third and fourth sections of the article give a brief overview of the Latvian and Lithuanian diasporas in Kazakhstan for the purpose of comparison.

\section{Collection of personal data}

As noted above, the need to create a collection of personal data is due to the scarcity and fragmentation of the available information. The first steps in collecting and summarising personal data were taken in 2005-07 while working on my master's thesis The Estonian Diaspora of Kazakhstan: Historical and Social Aspects. ${ }^{6}$ Initially, my goal was to collect information only about Estonians in Kazakhstan, but during my research I came across similar information on Latvians and Lithuanians. I realised that the history of these diasporas in Kazakhstan has also not been studied, and hence I decided to expand the collection of personal data to include Latvians and Lithuanians.

Today, the collection of data includes 1,113 biographies, of which the largest part, namely 577 files, are biographies of Estonians, while 374 files store information on Kazakhstan's Latvians and 162 files are on Lithuanians. Since the data includes people from each of the three Baltic diasporas and covers more than a hundred years, it presents a variety of information for each category. Nevertheless, all categories include certain items of general information (surname and name, age or year of birth, place of residence

6 Mariya Oinas, Estonskaya diaspora Kazakhstana: istoriko-sotsialnyy aspekt (Kajnar, 2007). 
in Kazakhstan, information on the person's field of activity). Biographies of Estonian migrants and of those who applied for Estonian citizenship in the 1920 also contain information on their place of origin in Estonia. Records of repressed people include the date of arrest and conviction, the article of the criminal code according to which they were prosecuted, their sentence, and the date of rehabilitation.

The personal data in the collection is drawn from five main types of sources:

- Monographs and memoirs.

- Archival documents (published and unpublished).

- Articles of from the Kazakhstani media and local studies.

- Biographical directories and memoires.

- Online databases.

For the most part, the monographs and memoirs presented are from the period of Soviet historiography and have a strictly directed ideological concept. In the works mentioned below, attention is paid only to those people whose activities fit in with the communist ideology (revolutionaries, Communist Party leaders, members of the Red Army).

Some monographs, such as Viktor Maamägi's study Estonians in the USSR (1990), are based on censuses and complied statistical data, and include limited biographical materials. Some additional personal information can be found in books on World War II (1939-45), for example the studies The Estonian People in the Great Patriotic War (1973) and The Fight of the Latvian People in the Days of the Great Patriotic War (1970). These contain brief biographical entries on Estonians and Latvians who were evacuated to Kazakhstan, and on their activities in the rear area. ${ }^{7}$ Memoirs are a valuable source of personal information because they include not only names and events, but also personal impressions of events. We include fiction in this category, for example, the works of the Estonian writers Debora Vaarandi and Aadu Hint, who were evacuated to Kazakhstan and later reflected on their years of exile in their books and memoirs. ${ }^{8}$

\footnotetext{
7 Viktor Maamägi, Estoncy v SSSR 1917-1940gg, 2-e izd., pererab. i dop. ed. (Moscow: Nauka, 1990); Estonskiy narod v Velikoy Otechestvennoy voyne Sovetskogo Soyuza 1941-1945, ed. by L. N. Lentsman, I. Trull, 2 vols. (Tallinn: Eesti Raamat, 1973), I; Borba Latyshskogo Naroda $v$ Gody Velikoy Otechestvennoy Voyny. 1941-1945, ed. by Aleksandr Drizul (Riga: Zinatne, 1970).

8 Aadu Hint, 'Istoriya moyey pervoy knigi', Svoy ostrov (Moscow: Sovetskiy pisatel, 1987); Aadu Hint, 'Polnyy vpered!', Svoy ostrov (Moscow: Sovetskiy pisatel, 1987); Debora Vaarandi, 'Zelenaya Alma-Ata', Izbrannoye (Moscow: Khudozhestvennaya literatura, 1986), 17-18.
} 
Campaign booklets published by the General Directorate of Resettlement and Recruitment of Workers under the direction of the Council of Ministers of the Kazakh SSR in the 1950 s and 1960 s can also be placed in this source category. The booklets have similar names (e.g. Move to us in Kazakhstan!) and themes (letters from migrants to their homeland about their lives in their place of resettlement).

Certainly, a large amount of biographical information is stored in archives. The Archive of the President of the Republic of Kazakhstan (Almaty) is the former archive of the Communist Party of Kazakhstan. The collections of the regional branch of the Communist Party (Kyrgyz Regional Committee of the RCP(b) - Kazakh District Committee of the AUCP(b) - Central Committee of the CPK) hold documents with biographical information about Estonian, Latvian, and Lithuanian communists, including evacuated people. ${ }^{9}$ The collection of the East Kazakhstan Regional Administration of the NKVD in the East Kazakhstan State Archive (in Ust-Kamenogorsk) contains biographical materials on Latvians, Lithuanians and Estonians who were repressed in the 1930s. I have also used archives of personal origin on the Latvians J. J. Yaunrodzin (who was an editor of several local newspapers in the 1930s) and R. A. Dreyman (who was a manager at the Ridder Mine from 1921 to 1926). ${ }^{10}$

The Central State Archive of the Republic of Kazakhstan contains prerevolutionary era documents from all regions of the republic. Documents in collections nos. 369 and 469 on peasant resettlement provide a view of the time and process of Estonian migration to Kazakhstan. They include requests for accommodation, the results of a survey of resettlement sites, loans, and land disputes with the local population. Collection no. 501 of the Akmola-Semipalatinsk Department of Agriculture and State Property serves as a source on the economic activities of peasants in the early twentieth century.11

9 Henceforth APRK F.139 Kirobkom RCP(b); APRK F.141 Kazkraykom VKP(b); APRK F.708 CK KP Kazakhstana.

10 Henceforth GAVKO F.P-462 Vostochno-Kazakhstanskoye oblastnoye upravleniye Narodnogo komissariata vnutrennikh del Kazakhskoy SSR g. Ust'-Kamenogorsk Vostochno-Kazakhstanskoy oblasti; GAVKO F. P-5 Jan Janovich Yaunrodzin; GAVKO F.53.3 Rudolf Ansovich Dreyman.

${ }_{11}$ Henceforth CGARK F. 369 Akmolinskoye oblastnoye pravleniye Ministerstva vnutrennikh del (1869-1918 gg.) (Akmola Regional Board of the Ministry of Internal Affairs (1869-1918)); F. 469 Zaveduyushchiy pereselencheskim delom $v$ Semipalatinskom rayone (Head of resettlement in the Semipalatinsk district); F. 501 Akmolinsko-Semipalatinskoye upravleniye zemledeliya i gosudarstvennykh imushchestv (Akmola-Semipalatinsk Department of Agriculture and State Property). 
Information from the 1917 agricultural census may be of interest to researchers. This data will help reconstruct the socio-economic situation of the Estonian village on the eve of the revolution. The peasants who migrated from Estonia to Kazakhstan represented the poor stratum of the Livland peasantry. Therefore, it is especially interesting to know whether they managed to get on their feet in the new place. Moreover, did emigration justify the strength and energy that they exerted? Aadu Must copied some documents from this archive for the Estonian National Archives, in particular the 1917 census cards for three villages in the Akmola region (Petrovskoe, Liflyandskoe and Sopetovo). In total, there are more than five hundred census cards. Each card is a table of 130 columns. The census was detailed and contains the following data:

- information on the family, the age and gender of its members, the date of relocation to Kazakhstan, and the province of exit. The presence of families with disabilities. The participation of each family member in the household;

- land ownership (farm or community land use) and land lease;

- cultivated crops (wheat, barley, potatoes, etc.);

- numbers and availability of livestock;

- types of agricultural tools and their ownership or rental. ${ }^{12}$

Collections nos. 367, 369, and 372-374 of the Estonian National Archives contain many documents from the late nineteenth to the early twentieth centuries on the resettlement of Estonian peasants to other regions of the Russian Empire, including the Kazakh steppe. These documents provide extensive biographical information: personal data on the migrant, their family composition and welfare, as well as the date and place of their intended relocation. While the documents of the commissioners of rural affairs often record only the intention to relocate, the documents of the Control-Repatriation Commission include personal information about those who relocated. The collection 'Siberi Kontroll-Opteerimise Komisjon' is particularly interesting because it contains the cases of the Omsk ControlRepatriation Commission to which Kazakhstan's Estonians belonged in the 1920 . $^{13}$ The collection contains more than eight thousand cases. It has an unfortunate feature that makes it difficult to study: it is impossible to search the documents using any search criteria other than last names (this

\footnotetext{
12 CGARK f. 393 Akmolinskiy oblastnoy statisticheskiy komitet (Akmola Regional Statistics Committee) 2.1.412 Petrovskoe; 2.1.415 Sepetovo; 2.1.473 Liflyandskoe.

13 Rahvusarhiiv (Estonian National Archives, henceforth RA), ERA 33 Siberi KontrollOpteerimise Komisjon.
} 
is great for genealogical research but complicates research work). Therefore, each case must be examined based on the applicant's residence. Currently, we have studied almost 3,200 files and identified 207 belonging to Estonians living in Kazakhstan at the time of filing the application. These documents provide a variety of data for study, for instance, the date of relocation to Kazakhstan, the place of emigration from Estonia, the composition of families, the place of relocation in Kazakhstan, as well as personal circumstances and occupations.

Even though we have a list of Estonian surnames found in Kazakhstan (more than five hundred surnames in total), the study of documents of the Control-Repatriation Commission was carried out in alphabetical order. The fact is that the available surnames, for the most part, belong to Estonians living in the four largest villages (Petrovskoe, Liflyandskoe, Verhnyaya Elovka and Nizhnyaya Elovka). Thus, if we check only these names, then Estonians living in cities and nationally mixed settlements are overlooked. This complete verification of profiles has already yielded results. Using this method, another place densely settled by Estonians in Kazakhstan is revealed: the village of Bodaj Kuduk (Alexandrovskaya volost, Pavlodar district, Semipalatinsk province).

Estonian settlements in Kazakhstan have often been a topic of interest to Kazakhstani journalists and local historians. Thus, the journalist Leonid Bill from Akmola dedicated his article 'The village at Juksar Hill' (1993) to the centenary of the Estonian village of Petrovskoe.

Yuri Popov, a well-known Kazakhstani historian of local lore, has been covering the history of villages of Central Kazakhstan in the press for many years. He has drawn attention to the Estonian village of LiflyandkaPokornoe. In addition, 1997 was declared the Year of National consent and memory of victims of political repression in Kazakhstan, during which the media published many memoires and interviews with repressed, deported Kazakhstanis and their descendants. ${ }^{14}$

The biographical reference book National commissioners of Kazakhstan: 1920-46 supplemented the personal database with information about Latvians, Lithuanians and Estonians who held senior positions in the government of the Kazakh SSR..$^{15}$ Unfortunately, the handbook provides

14 Yuriy Popov, 'Zapovednyye tsennosti Saryarki', Industrialnaya Karaganda, 3 December 2016, 4; Leonid Bill', 'Selo u sopki Yuksari. K 100-letiyu sela Petrovka', in Istoriya nashikh sel (Akmola, 1993), 72-78; Olga Zhandabekova, 'Lidiya Svara', Rudnyy Altay, 8 July 1997, 2.

15 Narkomy Kazakhstana. 1920 - 1946 gg. Biograficheskiy spravochnik, ed. by M. Zhakypov, A. Zulkasheva (Almaty: Arys, 2007). 
only biographical information and omits the activities of the persons who served in these posts.

The rapid development of digital technologies at the beginning of the twenty-first century led to the expansion of the source base due to the widespread emergence of online historical and genealogical resources. One such resource is the Otkrytyy spisok ('Open List') project, a database of all repressed people throughout the entire existence of the Soviet Union. ${ }^{16}$ It is based on data from memoires, as well as information provided by former KGB personnel. Personal information is presented within the framework of a unified questionnaire including the subject's name, year and place of birth, nationality, place of residence and work, dates of arrest and conviction, article under which they were convicted, sentence and time of rehabilitation. These data allow analysis not only of the nature and scale of repressions against Estonians, Latvians, and Lithuanians in Kazakhstan but also of some other questions (for example, the places of emigration, places of concentrated settlement in the republic, etc.). Thanks to this project, our collection of personal data has been supplemented with more than 600 biographies.

In 2010, at the initiative of the Ministry of Defence of the Russian Federation, the electronic resource Podvig naroda ('People's Feat') was opened, the purpose of which was to collect information in one place on all decorated participants in the Second World War. Five years later, another site, Pamyat' naroda ('Memory of the People'), was opened. It combined not only information on those who were decorated, but also on participants in the war who were killed or went missing. ${ }^{17}$

Both projects are focused on genealogical research, which presents us with a great challenge. Because the search is limited to personal data (name, year and place of birth or military recruitment), it is impossible to limit search criteria to representatives of any one nationality or soldiers from any one division. Therefore, we searched by last name in our data.

The online database Nomenklaturnyye kadry Sovetskogo Kazakhstana ('Nomenklatura Personnel of Soviet Kazakhstan') was created by the Archive of the President of the Republic of Kazakhstan. It is based on available documents of the Communist Party of the Kazakh SSR. This

\footnotetext{
16 'Otkrytyy spisok' <https://ru.openlist.wiki > [accessed 1 May 2019].

17 'Podvig naroda' <http://podvignaroda.ru $>$ [accessed 1 May 2019]; 'Pamyat' naroda' $<$ https://pamyat-naroda.ru $>$ [accessed 1 May 2019].
} 
online project supplements the biographical reference book National commissioners of Kazakhstan: $1920-46$ and covers the period from 1919 to $1991 .{ }^{18}$

An additional source was made available when some museums in Kazakhstan began to publish their databases, for example, the museums of Karlag and the Akmola Camp for Wives of Traitors to the Motherland (ALZhIR). These sources contain information on people who served sentences in the Gulag camps. It is worth noting that this process has only just begun, and the data presented are incomplete. ${ }^{19}$

Information from different sources complements one another and creates a general picture. This can be demonstrated with the example of the Vaaks family. According to an article by the Kazakhstani journalist Leonid Bill', Peter Vaaks was one of the founders of Petrovskoe, the first Estonian settlement, located in Novo-Cherkasskaya volost, Akmola District, Akmola province. This is also confirmed by the data of the Siberian Department of the Repatriation Commission: Peter M. Vaaks (1854) moved in 1871 from Orava Rural Municipality, Võru County in the province of Livland to Samara province. He had a son named Karl there in 189o. Later the Vaaks family set out again and moved to the Petrovskoe settlement in Akmola District. The fact of the foundation of the first Estonian settlement in Kazakhstan by Estonian colonists from Samara and Ufa provinces is also confirmed by August Nigol (1918). In October of 1920, Peter Vaaks and his sons applied for Estonian citizenship, but they remained in Kazakhstan. Ten years later, in 1930, Peter's son Karl Vaaks was arrested by the $O G P U$ and charged with terrorist activities and anti-Soviet propaganda. According to the database Otkrytyy spisok, Karl Vaaks was sentenced to 10 years of forced labour. These data are confirmed by L. Bill': 'Millers lost their homes and windmills. They took away everything from one of the founders of Petrovskoe, Peter Vaaks, and took him away with his family.' But the story of the Vaaks family in Kazakhstan does not end there. According to documents from the open source Podvig naroda (based on materials of the Central Archive of the Ministry of Defence of the Russian Federation), in November of 1943, Oskar, the son of Peter Vaaks, was drafted by the Red Army (according to other data his name was Oswald). He served as a rifleman in the $249^{\text {th }}$ Estonian Rifle Division and served with

\footnotetext{
18 'Nomenklaturnyye kadry Sovetskogo Kazakhstana' <http://archive.president.kz/ru/ nauka/nauchno-metodicheskaya-deyatelnost/bd-nomenklaturnye-kadry-sovetskogo/\#> [accessed 1 May 2019].

19 'Karlag NVKD' < https://karlag.kz> [accessed 1 May 2019]; 'ALZhIR' <https:// museum-alzhir.kz/ru/o-muzee/statistika> [accessed 1 May 2019].
} 
distinction in the battles of Saaremaa in 1944. Oskar Vaaks was awarded the medal 'For Courage'. ${ }^{20}$

Thus, our data collection is based on a wide range of diverse sources. Qualitative and quantitative research designs were adopted to provide data on the following:

- Regions of emigration of peasant colonists from Estonia;

- Chronological framework for the main stages of emigration from Estonia, Latvia and Lithuania;

- Areas of compact residence of Latvians and Estonians in Kazakhstan, as well as the approximate number of settlements;

- $\quad$ Extent of repression against Estonians, Latvians and Lithuanians in Kazakhstan;

- Participation of Estonians, Latvians, and Lithuanians from Kazakhstan in World War II as part of the Red Army. ${ }^{21}$

Although the collection of data uses a wide range of sources, there are still opportunities for expansion. So, data from the agricultural census of 1917 in the Akmola region (collection 393 of the CGARK) are not covered. Moreover, while data are available for the Akmola region, then identification of agricultural census documents from 1917 concerning the Semipalatinsk region remains to be done. We can only assume the presence of such documents on the Estonian settlements in this region (Verhnyaya Elovka, Nizhnyaya Elovka, Gerasimovka, Bodaj Kuduk). Working with the census data will help to ascertain the number of Estonians, Latvians and Lithuanians living in Kazakhstan on the eve of the October Revolution. In our opinion, information on citizens of Baltic nationalities who were repressed during the years of the Great Terror also remains incomplete. This line of research will continue as the National Security Committee of the Republic of Kazakhstan publishes the data.

Further, the article will present the results of our analysis in the context of each nationality. In addition to its research potential, the collection of personal data that we have created is also of practical importance. I have been approached repeatedly by Estonians who have roots in Kazakhstan for information about the lives of their ancestors.

Regardless of the long common history of belonging to the Russian Empire and the Soviet Union, many Kazakhstanis perceive Latvia,

\footnotetext{
$20 \quad$ Bill', 'Selo u sopki Yuksari'; RA, ERA, 33.2.7797: Vaaks, Karl Peetri p.; 'Vaaks Petr Karlovich', Otkrytyy spisok <https://ru.openlist.wiki> [accessed 1 May 2019]; 'Vaaks Oscar Petrovich', Podvig naroda $<$ http://podvignaroda.ru> [accessed 1 May 2019].

${ }^{21}$ Over the course of this research, information on the participation of natives of Kazakhstan who were of Baltic origin in the German army was not found.
} 
Lithuania, and Estonia as a single entity known as Pribaltica. In addition to their geographical location, their similar history plays an important role in this. Despite these factors, the diasporas of Estonians, Latvians and Lithuanians in Kazakhstan were formed in different ways. Below is a description of each diaspora.

\section{Estonians}

The Estonian diaspora in Kazakhstan started taking shape at the end of the nineteenth century. It should be noted that isolated cases of Estonians living in Kazakhstan can be found throughout the nineteenth century, but this was not a diaspora in the strictest sense. So, according to Aadu Must's remark, "Many who were sent "to Siberia" for penal servitude and resettlement actually appeared in the Kazakh land. ${ }^{22}$ Natives of the Baltic Sea region participated in the process by which Russia annexed Kazakhstan. The nobility of Baltic German origin played an essential role in the colonisation of the steppe region. So in different years, Hans Heinrich von Weymarn, Johann Clapier de Colongue, Gustav Ernst von Strandmann, Andreas Gotthard and Karl von Struve served in this territory. ${ }^{23}$

A complete geographical study of our fatherland (published in 1903) testifies that 'German colonists (Mennonites, Baptists, etc.), as well as Estonians and Latvians, appeared in the Akmola region only in the 189os; some of them came to live on leased sites near Omsk, others in the Akmola district on allotment land (villages of Preobrazhenskoe, Romanovskoe, Kankrinskoe). ${ }^{24}$

The first Estonian settlement in Kazakhstan was founded in 1893 in the Novo-Cherkasskaya volost, Akmola District of Akmola province, and was named Petrovskoe. Its founders were Hindrek Korol, Iohan Kukka, Jaan Raudik, Peter and Jacob Vaaks and Jaan Hütt. They were all peasants from Võru County in Livland. Based on the manuscript of the memoirs of Karl Treial, a descendant of the first Estonian immigrants, Leonid Bill' describes the history of the foundation of the village:

\footnotetext{
22 Aadu Must, 'Eesti ja Kasahstan', Postimees, 20 April 2011, online edition <https://arvamus.postimees.ee/422298/aadu-must-eesti-ja-kasahstan? $\mathrm{ga}=2.131597839 .12066880 .1572603296-958100294.1523875618>$ [accessed 1 May 2019].

23 Nemtsy Rossii, ed. by V. Karev, Obshchestvennaya Akademiya nauk rossiyskikh nemtsev, 3 vols. (Moscow, 1999).

24 Rossiya. Polnoye geograficheskoye opisaniye nashego otechestva. Nastol'naya i dorozhnaya kniga dlya russkikh lyudey. Kirgizskiy kray, ed. by Veniamin Semenov, 19 vols. (St Petersburg: A. F. Devrien, 1903), XVIII (1903).
} 
There were three friends, former soldiers of the imperial army, who spoke Russian well. They were also equipped for a long journey, having collected five roubles from each family to cover their travel expenses. The Estonians set out on foot, having been promised permission to settle in the steppes. They reached Petropavlovsk by train, and from there proceeded further into the steppe with a merchant caravan. Once the caravan stopped to rest at a picket post called Zhilandy near which a river flowed. The thrifty Estonian hikers decided to catch fish using a small fishing net that they had brought along on the journey. To their surprise, when they pulled out the dragnet, there were enough large and very tasty fish for the travellers in the caravan and the family of the picketer. ${ }^{25}$

The Estonians found this place attractive, and they requested assignment to Zhilandy. After receiving a positive decision, they returned to Estonia and began preparing to resettle with their families. The first group of immigrants set out on the long journey the following year. ${ }^{26}$ This is how Karl Treial describes the journey:

On the way here, people rode on horseback for a long time and slept in tents, with only a few dozen kopecks in their pockets. But on the way, the settlers met with the support of the population everywhere. In every village they were given food for the road, some villagers even gave clothes and shared everything they could. On the way, the immigrants had to earn extra money for food from wealthy residents and by working on the railroad. Then they moved on to Akmola District. ${ }^{27}$

It was here on the banks of the Ishim river near the place known to the Kazakhs as Zhilandy that the settlement of Petrovskoe was established. Therefore, in some sources both names are given. ${ }^{28}$

Over the next several years, peasants not only from Estonia, but also Estonian peasants from the provinces of Samara and Ufa as well as the

\footnotetext{
25 RA, ERA.33.2.7801: Vaaks, Peeter Mihkli p.; Bill', 'Selo u sopki Yuksari'.

26 CGARK, 369.1.4571: Prosheniye estontsev Veliko-Russkikh guberniy Stepnomu General-gubernatoru', 1894.

27 Bill', 'Selo u sopki Yuksari'.

28 For example, a note from the newspaper Akmolinskie oblastnye vedomosti dated 11 June 1907: 'On the morning of 6 June, in the places Uru-Cheku, Dzhily-sai, Dzhilandy and Kara-Tomar in Ishim municipality of Akmola District, hail the size of goose and chicken eggs rained down intensely. The hailstorm passed in two lines from Uru-Cheku in the direction of the village of Gulyai-pole and the villages of Petrovskoe and Pokrovskoye; grain crops and grassland were severely beaten down, and in some places, young lambs and poultry were killed by hailstones.'
} 
Crimea, moved to Petrovskoe. ${ }^{29}$ Confirmation of this fact can be found in the biographies of K. P. Vaaks, D. D. Piisang and K. J. Rosenberg. The fact is that none of them were born in the territory of Estonia, nor in Kazakhstan. K. P. Vaaks (born 1890) and K. J. Rosenberg (born 1895) were born in Samara province, and D. J. Piisang (born 1890) was born in Ufa province. ${ }^{30}$ At the same time, starting from 1899, there is data on births in the families of Estonian colonists who were already in Kazakhstan. Thus, it can be assumed that the resettlement of Estonians from the Urals to Kazakhstan took place in the short period of time between 1895 and 1899 .

The first general census of the population of the Russian Empire in 1897 makes it possible to establish the approximate number of Estonians in the Akmola district. According to the census, 316 people were identified as Estonian. Of these people, 150 were natives of the provinces of Livland and Estland. ${ }^{31}$

The life of the newcomers on the steppe was not easy. This is how L. Bill' describes it: 'Life was difficult for the founders of the village; it is not easy to till the centuries-old virgin soil with a single plough. Therefore, they worked together, uniting several families. They became acquainted with tamyrs, friends among Kazakhs from the nearest auls (meaning 'village' in Kazakhstani), and borrowed horses from them for field work. Some dug their fields with shovels. One can imagine that it was hellish work.' As a rule, wheat, oats, barley and peas were sowed. Rye, according to A. Nigol's remark, did not grow in the area. ${ }^{32}$ The immigrants very quickly became fully self-sufficient in terms of grain, and even began to sell it.

In addition to the settlement of Petrovskoe in Akmola province, Estonians lived in the Semipalatinsk (15 people), Turgai (14 people) and Syr-Darya (1 person) regions at the end of the nineteenth century. The total number of Estonians recorded by the 1897 census in the Kazakh provinces was 370 people. Of these, as noted above, 316 lived in Akmola District. Twenty-one Estonians lived in the cities of Akmolinsk, Ust-Kamenogorsk (in Semipalatinsk province), Uralsk (in Ural province) and Aulie-ata (in Syr-Darya

29 This is mentioned in the study by August Nigol Eesti asundused ja asupaigad Wenemaal (Tartu: Eesti kirjastuse ühisuse "Postimehe" trükk, 1918) and in Leonid Bill"s article 'Selo u sopki Yuksari'.

30 Nigol, Eesti asundused; 'K. P. Vaaks, D. D. Piisang, K. J. Rosenberg', Otkrytyy spisok $<$ https://ru.openlist.wiki> [accessed 1 May 2019].

31 Nikolai Trojnickij, Pervaya Vseobshchaya perepis' naseleniya Rossiyskoy imperii $1897 g$ (St Petersburg: Central Statistical Committee, 1904), 81 AкMolinskaya OBlast, 24-27, 50-51.

32 Bill', 'Selo u sopki Yuksari'; Nigol, Eesti asundused, 41. 
province, now Taraz city)..$^{33}$ Thus, the Estonian diaspora of Kazakhstan began to take shape in the last decade of the nineteenth century. Its number never exceeded 400 people.

In subsequent years, the resettlement of Estonians to the Akmola region continued. They settled in Russian and German settlements. According to A. Nigol, these settlements were Mikhaylovskoye, Novoyegoryevskoye and Vishnevskoye. The same data are also confirmed by official information from the office of the akim of the Baymyrza rural district (body of the local government). ${ }^{34}$

One resettlement site called Shokai, named after the springs flowing there, was opened for settlement in the Akmola district of the Akmola region in 1905. It was calculated on the basis of 638 land shares. ${ }^{35}$ Estonians from the nearest villages moved to this area, forming the Liflyandskoe settlement in 1906. The name paid homage to the place the Estonians had emigrated from - most of them were natives of Vorru County in the province of Livland.

August Otto and Samuel Kanter's families became two of the first Estonian families of Liflyandskoe. ${ }^{36}$ Besides them, the families of Abel, Ain, Annum, Velts, Hõrn, Goldstein, Derrik, Pähn, Raudsep, Tasso, Tätte, Uven, Haab, Hakmann, Herkmann, Hollo, Evert and Ess lived in Liflyandka.

Most of the inhabitants of Liflyandka had left Estonia during the period from 1899 to 1903 . Such a conclusion can be drawn based on analysis of the questionnaires submitted to the Siberian Control and Repatriation Commission (namely, Question 9 of the questionnaires: 'When did you move to Russia?'). Confirmation of this is found in other documents. For example, the biography of Jaan Samuili Kanter says that his parents were Estonians from Vorru County and that they were assigned to the village of Mikhailovskoe in the Kharkov volost of Akmola District in September of 1897. He was born there in 1903 and when he was three years old, his parents moved to Liflyandka. ${ }^{37}$

In 1909, six peasants from Kärstna Rural Municipality in Viljandi County submitted a petition to the Commissioner for Peasant Affairs of

\footnotetext{
33 Nikolai Trojnickij, Pervaya Vseobshchaya perepis' naseleniya Rossiyskoy imperii 1897 $g$ (St Petersburg: Central Statistical Committee, 1904), LXXXI-LXXXVIII.

34 Nigol, Eesti asundused; 'Pasport selskogo okruga Baymyrza' <http://bukhar-zhirau. gov.kz/ru/vlast_3_4_4/> [accessed 1 May 2019].

35 Obzor Akmolinskoy oblasti za 1905 god (Omsk: Akmola Statistical Committee, 1906), 9.

36 'Pasport selskogo okruga Baymyrza'.

37 RA, ERAF.1.6.6044, pp. 4-6: Jaan Kanter, 'Autobiography'.
} 
Akmolinsk district requesting that land be assigned to them. From the petition of Ivan Johanson,

Having learned from the local newspaper the contents of your speech delivered on 12 November 1908 to the peasants of the village of Liflyandka on the formation of Liflyand Parish, with a predominantly Estonian population, in Akmola District, and granting your gracious permission to the members of the said volost to invite new immigrants from among their relatives and friends in their homeland, I have the honour to ask Your Highness to record me with my family as members of the aforementioned 'Liflyandka' Parish. ${ }^{38}$

The applicants were denied because the transfer of land plots for that year had already been closed, and the transfer was not made in absentia.

However, the new settlers of Liflyandka could invite relatives from Estonia to join them if they secured land for them. Mihkel Jacob Lahk, Johan Jacob Palm and Gustav Petrov Hakman took advantage of this opportunity. They all had letters of invitation from relatives promising help in crediting land plots. ${ }^{39}$

The total number of Estonians who moved to the Kazakh steppes was small, both in comparison with other regions of Siberia, and in comparison to migrants of other nationalities. According to the certificate issued by the head of resettlement in Akmola District in 1910, 46 German settlements occupied only $4.42 \%$ of resettlement lands. This number includes sixteen villages located in the Omsk uyezd. Of the thirty German communities in Akmola, Kokchetav, Atbasar and Petropavl counties, only two were Estonian, namely Petrovskoe and Liflyandskoe. The small number of Estonians is also emphasised in the certificate: 'the Shokai section of Akmola District, where the Estonians are located, is the best evidence of how insignificant the movements of the Estonians and Latvians are. This site has not been settled for several years. ${ }^{30}$ By 1915, 479 Estonians (254 men and 225 women) lived in Liflyandskoe, and 354 Estonians lived in Petrovskoe (180 men and 174 women). ${ }^{41}$

38 RA, EAA.372.1.1669: Ivan Iohanson, 'Prosheniye krest'yanina Kerstenskoy volosti, Fellinskogo uyezda, Liflyandskoy gubernii Ivana Matfeyeva Iohansona', 1909.

39 RA, EAA.369.1.86, pp. 147-149, 210-214, 467-471: 'Protokoly i Perepiska s Volostnymi Pravleniyami o Pereselenii Krest'yan v Sibir'.

40 Pereselencheskaya politika tsarskogo pravitel'stva i yeye osushchestvleniye $v$ Vostochnom Kazakhstane (XVIII - nachalo XIX vv.): Sbornik dokumentov, ed. by A. Aubakirov, M. Yeskendirov (Semey, 2010).

${ }_{41}$ Pereselencheskaya politika tsarskogo pravitel'stva; A. Andretsov, 'Istoriya vozniknoveniya yevangelicheski-lyuteranskoy i baptistskoy tserkvey v Kazakhstane v XIXv.', 
Aside from Central Kazakhstan, Estonians also moved to East Kazakhstan. In 1905-06, places of resettlement were formed in Zaysan District along Lake Markakol on the border with China. The lake is in the Altai Uplands and is a remote place even today. This is how nature is described at these sites:

There will be three places for resettlement near the lake. The relief of all these sites is very undulating. The higher elevations are covered with dark-coloured loams. Flat areas are covered by chernozem with steppe vegetation, hayfields and small deciduous forests. Suitable for both agricultural and cattle farms. ${ }^{42}$

This is how Rosalia Oinas (née Varblane), daughter of one of the Estonian colonists, described the resettlement process:

My husband [Karl Jaani Oinas] was six years old when they left their home in Estonia. They travelled by horse across the whole of Russia. Having reached Bayanaul, they stopped and sent two people on foot to look for a place for a village. They really liked Lake Markakol: beautiful, rich in fish, forests all around. So they decided to stay there. ${ }^{43}$

By 1908, after completing a two-year journey, new Estonian settlers arrived at a place where they established several settlements, which later developed into the villages of Verhnyaya Elovka and Nizhnyaya Elovka. The Varblane, Visman, Kirspuu, Oinas, Holman, Puusep, Samul, Zimmer, Chakhno and Jun families were among the migrants.

It should be noted that unlike in Central Kazakhstan, where Estonians tried to settle compactly, Estonians in East Kazakhstan often moved to ethnically mixed villages. Verhnyaya Elovka and Nizhnyaya Elovka are rather exceptional cases where Estonians formed separate communities. Estonians lived in different villages in the Glubokovsky District of East Kazakhstan: the Amos, Graf, Kutser, Lill, Marlat, Mateus, Männi, Ottens, Piksaar, Raudsep, Rebane, and Taldrik families.

The most significant portion of the Estonian immigrants to Kazakhstan came from Vorru County in the province of Livland. These were mainly poor peasants, hired workers, and farm labourers. First they set out to emigrate to the Ural provinces (Samara and Ufa governorates), or to Siberia. However,

\footnotetext{
Vysshaya shkola Kazakhstana, 2003, 185-191.

42 Pereseleniye i zemleustroystvo za Uralom v 1906-1910gg. (Petrograd: Tipografiya M. P. Frolovoy, 1911), 175.

43 Rosalia Oinas (née Varblane), interview, 2003. The transcript of the interview is at the disposal of the author.
} 
having failed to gain a foothold there for various reasons, they were looking for free land in other regions. They found it in the Akmola and Semipalatinsk regions, where there was still enough free land for settlement. ${ }^{44}$

The Estonians who moved to the provinces of Akmola and Semipalatinsk experienced difficulties in the first years. However, as a result of working together, a few years later they were able to not only provide for themselves but could also sell their harvest. The Kazakh historian Nailya Bekmahanova notes that Estonians cultivated not only grain but also potatoes for sale, and that in Estonian villages, commodity production was dominant from the beginning ${ }^{45}$ Bekmahanova considers the multifield farming method introduced by Estonians, the use of modern agricultural knowledge acquired in their homeland, as well as the active use of various techniques, to be the reasons for their rapid economic growth. In Petrovskoe there were several windmills, and a water mill was erected on the Ishim River, which was dismantled for the winter, and reassembled after damaging floods.

Estonian immigrants maintained their way of life, customs and traditions but borrowed some elements of material culture from the Kazakhs. For example, houses in the province of Akmola were built out of samans (unfired bricks made from clay mixed with straw). Karl Treial, a resident of Petrovskoe, tells in his memoirs:

Now houses were built mainly out of saman, with two rooms. Walls were built quite thick using one and a half saman. They were coated with clay every year, since the rains washed away the clay. Roofs were covered with straw or reeds, with a layer of soil on top; floors were earthen, rarely wooden. Earthen floors were made as follows: first they poured a layer of straw, pounded it until it became hard, then smeared it with a thick, uniform layer of clay mixed with chaff. In addition, the floors were smeared with a thin layer of clay solution mixed with mullein each week. Over time, the floor became durable and dry. Utility rooms (kitchens, pantries, cellars, and baths) and a shed for livestock were attached to residential buildings. We immediately dug a well. And all this under the same roof. During winter storms, the hosts did not go out of their yard for weeks. Cellars were usually dug in two parts. In one they kept potatoes and vegetables, while the other cellar was filled with ice in winter,

${ }_{44}$ Jüri Meomuttel, Eesti Asunikud Laialises Wene Riigis: Esimene Katse Sõnumid Kõikide Eesti Asunduste Üle Tuua (Jurjev: Postimees, 190o); Nigol, Eesti asundused.

45 Bekmahanova, Mnogonatsionalnoye naseleniye Kazakhstana, 216. 
and then in the summer it served as a refrigerator. Grain barns were usually built separately from the house and other buildings. ${ }^{46}$

Anna Petrovna Jun, whose family moved to Markakol, remembers the difficult first years:

Arable land was expanded by rooting out woods. A large dairy herd and pigs were gradually acquired. Cattle were acquired more quickly than in the Baltics, but there was no place to sell butter and meat, lard and honey; there was no place to get a plough, a seeder, or a separator. In any case, a pound of salt was more expensive than gold. ${ }^{47}$

Practically all researchers and journalists have noted that the Estonian settlers were masters of all trades, women were engaged in needlework and weaving, and men were engaged with handicrafts. Each farm fully provided for itself not only in terms of food, but also household items, clothing and shoes. For example, a resident of Petrovskoe, Willem Lepmets, had a lathe and made spinning wheels and weaving machines for his fellow villagers. Meanwhile, Jacob Rebson was engaged in carpentry and made carts and sleighs, bent arcs and even made wheels for carts. ${ }^{48}$

A prayer house and a school were the first buildings to be built in every Estonian village (a church was built later). A four-year school was built in Petrovskoe and Hindrek Piisang became its first teacher, but was later replaced by Juri Lipp. A three-year rural school was opened in Liflyandka around 1914, prior to which children had studied in the neighbouring village of Astakhovskoye. ${ }^{49}$

According to the memoirs of J. Kanter, school was where Estonian children first became acquainted with the Russian language:

In the beginning it was not easy. The difficulty was that there were no hissing letters in the Estonian language or its alphabet. It showed up in 'skola' (school), 'spitsi' (forceps), 'setka' (brush), etc. But then we gradually learned. By the spring and by the end of the school winter, I was already more or less properly speaking and reading Russian. ${ }^{50}$

\footnotetext{
$46 \quad$ Bill', 'Selo u sopki Yuksari'.

47 A. Rozanov, 'Trista devyanosto chetvertyy i daleye. V doline reki Kal'dzhir', Leninskaya smena (Ust-Kamenogorsk, 13 December 1974), 3.

48 Bill', 'Selo u sopki Yuksari.'

49 Bill', 'Selo u sopki Yuksari.'; RA, EAA.372.1.1209: Yuriy Lipp, 'Prosheniye uchitelya seleniya Petrovskogo Novo-Cherkasskoy volosti Akmolinskogo uyezda Yuriya Martova Lipp', 1903; Popov, Zapovednyye tsennosti Saryarki.

50 Jaan Kanter, 'Pis'mo vnukam', Rassvet-Tokarevka (Karaganda oblast, 23 July 1977), 3.
} 
It is worth noting that the first generation of Estonian peasant migrants did not learn to speak Russian well. Estonians who settled in cities or in Russian villages learned Russian better. On the other hand, many Estonians quickly mastered the Kazakh language since they coexisted with the Kazakh auls. For example, they traded, settled land use issues and hired rich Kazakh bais (especially in the first years after the resettlement). In general, relations between Estonians and Kazakhs were friendly, as noted by L. Bill': 'The Kazakhs of the neighbouring villages came to Petrovka to visit friends, exchange news and conclude contracts. Almost every villager had his close friend tamyr. In turn, the Estonians visited the Kazakhs. ${ }^{51}$

After leaving their homeland, the Estonians continued to keep in touch with their relatives, subscribe to Estonian newspapers and preserve their traditions. Karl Treial recounts an interesting wedding tradition in his memoirs:

Weddings were carefully prepared for long in advance. Especially magnificent weddings were organised by wealthy villagers. They built models of sailing ships on wheels, and locomotives that smoked and puffed. An orchestra was placed on the deck of the ship along with the bride and groom, who were accompanied by youths in sailor's uniforms. The ship and the locomotive moved through the village from the groom's house to the bride's house and back. At weddings, guests fired rifles and, of course, danced, told humorous stories and sang songs. ${ }^{52}$

There were practically no ethnically mixed marriages; as a rule, Estonians married Estonians.

The subsequent years before the outbreak of the First World War were marked by isolated cases of Estonians resettling to Kazakhstan. The majority of Estonian colonists relocated to the Tomsk and Yenisei provinces, as well as to the Far East. In the period from 1910 to 1917, the following persons moved to Kazakhstan with their families: I. G. Viira and M. M. Eer (to Western Kazakhstan), P. I. Olekse, M. M. Paur, V. J. Sikk and J. A. Hakk (to the Akmola region).

With the beginning of the First World War, German toponyms were Russified throughout the Russian Empire. This affected not only the capital St Petersburg, which was renamed Petrograd, but also small settlements. Among them was the settlement of Liflyandskoe, which was renamed Pokornoe.

$51 \quad$ Bill', 'Selo u sopki Yuksari.'; Popov Zapovednyye tsennosti Saryarki; Bekmahanova Mnogonatsionalnoye naseleniye Kazakhstana.

52 Bill', 'Selo u sopki Yuksari.' 
According to the Tartu Peace Treaty between Estonia and Soviet Russia, persons of Estonian origin residing in Russia could opt for Estonian citizenship and leave Russia. Estonians residing in the territory of modernday Kazakhstan were allowed to apply for Estonian citizenship through the Control-Repatriation Commission in Omsk. So far, we have identified 207 applications filed by Estonians in Kazakhstan. Together with family members, 642 people hoped to opt for Estonian citizenship. Helen Rohtmets-Aasa distinguishes three types of repatriates to Estonia in the early 1920s: refugees of World War I; people living in countries with which bilateral agreements had been concluded (Soviet Russia, Ukraine and Latvia) who wanted to gain Estonian citizenship; all others who wished to opt for Estonian citizenship and who did not live in countries with which bilateral agreements had been concluded. ${ }^{53}$ An analysis of the profiles of applicants from the collection of the Control-Repatriation Commission shows that among the applications submitted from Kazakhstan, representatives of the second category prevail (191 requests). The number of refugees was small (sixteen applications). More than half of the applicants lived in the Akmola region (Pokornoe - 58, Petrovskoe - 51, Sopetovskoe - 22). ${ }^{54}$ The peak in applications came in the autumn of 1920. As evidence of their Estonian origins, applicants submitted excerpts from church birth registers and resettlement documents. The precise number of applicants who received Estonian citizenship, as well as those who returned from Kazakhstan to Estonia, remains unknown.

According to the 1926 All-Union Census of the Soviet Union, 2,192 people of Estonian nationality lived in Kazakhstan..$^{55}$ Over the next three decades (from 1920 to 1952), repression in the Soviet Union affected representatives of all nationalities and all regions of the country. Estonians, Latvians and Lithuanians living in Kazakhstan were no exception. Analysis of the data in the Otkrytyy spisok allows us not only to trace the scale and dynamics of repression, but also to ascertain the most frequently enforced articles of the criminal code, as well as the specific sentences handed down.

The history of the Soviet Union is closely connected to the policy of repression against a wide range of peoples. Beginning as the Red Terror against the 'enemies of the revolution' during the Civil War, the policy of

53 Helen Rohtmets-Aasa, Eesti Vabariigi sisserändepoliitika aastatel 1920-1923, Dissertationes historiae Universitatis Tartuensis, 33 (Tartu: University of Tartu Press, 2014).

54 'Optantide Isiklikud Toimikud. Siberi Kontroll-Opteerimise Komisjon', 1920, RA, ERA.33.2.

55 Vsesoyuznaya perepis' naseleniya 1926g. (Moscow: izdatel'stvo TSSU SSSR, 1928), VIII KAZASSR, KIRGIZSKAYA ASSR, 15-45. 
violence continued through dispossession and in dozens of show trials, and reached its zenith during the Great Terror (1937-38). The ideological basis and justification for the policy of mass purges was Stalin's doctrine of 'intensification of the class struggle as socialism is completed'. He expressed it at the Central Committee plenum in July of 1928. According to this doctrine, repression against different social groups was considered a legitimate and necessary measure on the way to a better socialist community. As the Russian researcher Stepanov notes, 'Soviet historical science under the leadership of Stalin was able to build a fairly logical chain of evidence of the need to destroy the so-called bourgeois classes. ${ }^{56}$

In 1934, Stalin used the murder of Sergey Kirov as a pretext to launch the Great Terror. Repressions in the army followed the purge of Communist Party ranks. The fight against 'enemies' unfolded across the country. Everywhere the NKVD 'identified' organisations, centres, blocs and groups of spies, terrorists and pests. A large number of organisations (NKVD agencies, troikas, the military collegium, courts at various levels, tribunals) participated in the repression process. However, even though formally speaking, numerous institutions were involved in 'investigations', their tasks did not include detailed and honest inquiries of alleged crimes - most judgments were delivered in absentia without the involvement of the accused and their legal defence. Troikas handed down death sentences according to lists and by the conveyor method. ${ }^{57}$ The basis of indictments was false confessions extracted by torture.

In 1937-38, a series of Yezhov's directives drove a mechanism of mass repressions against ethnic minorities living in the USSR (Germans, Poles, Romanians, Latvians, Estonians, Lithuanians). The NKVD considered representatives of these nationalities to be part of a support network for foreign intelligence services. The largest of these ethnic NKVD operations was the Polish Operation, which began on 20 August 1937, based on the NKVD order No. 00485. During this operation, not only ethnic Poles, but also other nationalities were arrested (including Latvians, Lithuanians, and Estonians). ${ }^{58}$ After the Polish Operation, analogous ethnic operations followed against Romanians (August 1937), Latvians (November 1937),

56 Mihail Stepanov, 'Stalinskaya repressivnaya politika v SSSR (1928-1953 gg.): vzglyad sovetskoy istoriografii', Izvestiya Altayskogo gosudarstvennogo universiteta, 2008, 131-37 <https://cyberleninka.ru/article/n/stalinskaya-repressivnaya-politika-vsssr-1928-1953-gg-vzglyad-sovetskoy-istoriografii/viewer> [accessed 7 January 2020].

57 Aadu Must, 'Venemaa eestlased ja Suur Terror. Elektroonilite allikapublikatsioonide andmete kriitiline analüüs', Ajalooline Ajakiri, 3, 2002, 47-84.

58 Must, 'Venemaa eestlased ja Suur Terror', 59. 
Greeks (December 1937), Estonians, Lithuanians and Finns (December 1937), Iranians (January 1938), Bulgarians and Macedonians (February 1938). It should be noted that this distinction is very arbitrary because, in the course of any ethnic operation, the NKVD could arrest any representative of national minority groups. In contrast to the dekulakisation campaign, local NKVD authorities did not receive specific figures on the number of arrests that were to be made. They were free to determine the quantity and composition of 'national enemies'. NKVD order No. 00485 adopted the simplified so-called 'album procedure' for all ethnic operations. The lists of people condemned by a lower NKVD organ were collected into 'albums' and sent to Moscow for approval by the joint committee of the NKVD and the USSR Prosecutor's Office. Later this system was replaced by 'special troikas', the sentences of which no longer required approval from central authorities. Over the course of two months of activity, the troikas examined 108,000 cases and pronounced 72,000 death sentences ${ }^{59}$ In total for all ethnic operations (from 25 August 1937, when the first album was signed, until 17 November 1938) that implemented the 'album procedure', troikas judged the cases of 346,713 people, of which 335,513 were convicted, including 247,157 people sentenced to be executed. That is $73.66 \%$ of the whole number of convicts. ${ }^{60}$

Estonians, Latvians and Lithuanians living in the Kazakh SSR also fell victim to the Great Terror. We took data for analysing repressions from the Otkrytyy Spisok of the Memorial, supplemented by information from Kazakhstani collections (Books of Memory and Books of Sorrow (execution lists)). It is important to note that work to improve these data is still ongoing, which means that the sums given can be regarded as minimal. The first arrests of Estonians, Latvians and Lithuanians took place in the 1920s. The total number of people arrested at that time amounted to sixteen people (five Latvians, two Lithuanians and nine Estonians). In the 1930s, before the start of ethnic operations, the total number of people arrested increased to fifty-three (twelve Latvians, five Lithuanians and thirty-six Estonians).

The peak of arrests occurred during the NKVD ethnic operations. In two years (1937-38), 377 people were arrested (135 Latvians, 47 Lithuanians and 195 Estonians). Speaking of Estonians throughout the Soviet Union

\footnotetext{
$59 \quad$ Ibid.

60 Petrov, N. B. and A. B. Roginsky, 'Pol'skaya Operatsiya NKVD 1937-1938 Gg.', Repressii Protiv Polyakov i Pol'skikh Grazhdan, Istoricheskiye Sborniki 'Memoriala', Zven'ya (Moscow, 1997) <http://old.memo.ru/history/polacy/o0485ART.htm>.
} 
who were later sentenced to be shot, the most significant number of arrests was made in August-November of 1937. The second wave occurred in February-March of $1938 .{ }^{61}$ In the Kazakh SSR, the situation was similar: there were two waves of arrests as well, the first in November of 1937 (eighteen Estonians arrested) and the second in February-March of 1938 (eighteen and thirty-five people, respectively). ${ }^{62}$

The first wave of executions of the Great Terror in the USSR began in August-September of 1937. However, the bloodiest month for the Estonians of the Soviet Union was November of 1937. In just the last four months of the year, about 60 per cent of the Estonian victims of the Great Terror were executed. ${ }^{63}$

In Kazakhstan, the situation was slightly different. Of the 195 Estonians arrested in Kazakhstan during the Great Terror, more than 75 per cent (148 people) were sentenced to death. In the regional context, the most significant number of executions was handed down in the East Kazakhstan region (fifty-nine executions) and the Karaganda region (thirty-six executions). Thanks to the publication of the Book of Sorrow (shooting lists) for the East Kazakhstan region, we can quite accurately reconstruct how the death penalty was carried out. Here the shootings of Estonians started in November of 1937 (three people shot). The peak occurred in AugustNovember of 1938: fifty-one people were shot during these months, while the largest numbers of people were executed on 11 August 1938 (ten people) and 3 November 1938 (eleven people). In the Karaganda region, the peak of executions occurred in October of 1938 when twenty-nine Estonians were shot (which is 80 per cent of the Estonians who were sentenced to death in this region). ${ }^{64}$

In the course of studying the 'Kniga Skorbi' (Book of Sorrow), we found one case that well illustrates the 'album procedure' for death judgments. Andrei Antonovich Rebane lived in the East Kazakhstan region. He worked at the mine and was arrested on 4 April 1938. On 2 November, the NKVD troika convicted him and sentenced him to death. Perhaps Rebane would have been executed with other Estonians the next day, and thus would have become the twelfth person on the list. However, he died in July of 1938 in an NKVD prison. This fact did not stop the troika from convicting Rebane and sentencing him to death. ${ }^{65}$

\footnotetext{
${ }_{61}$ Must, 'Venemaa eestlased ja Suur Terror', 66.

62 Ibid.

63 Must, 'Venemaa eestlased ja Suur Terror', 67.

64 'Otkrytyy spisok'.

65 'Otkrytyy spisok'; Kniga skorbi (rasstrel'nyye spiski) (Semey: Semey-Pechat', 2001).
} 


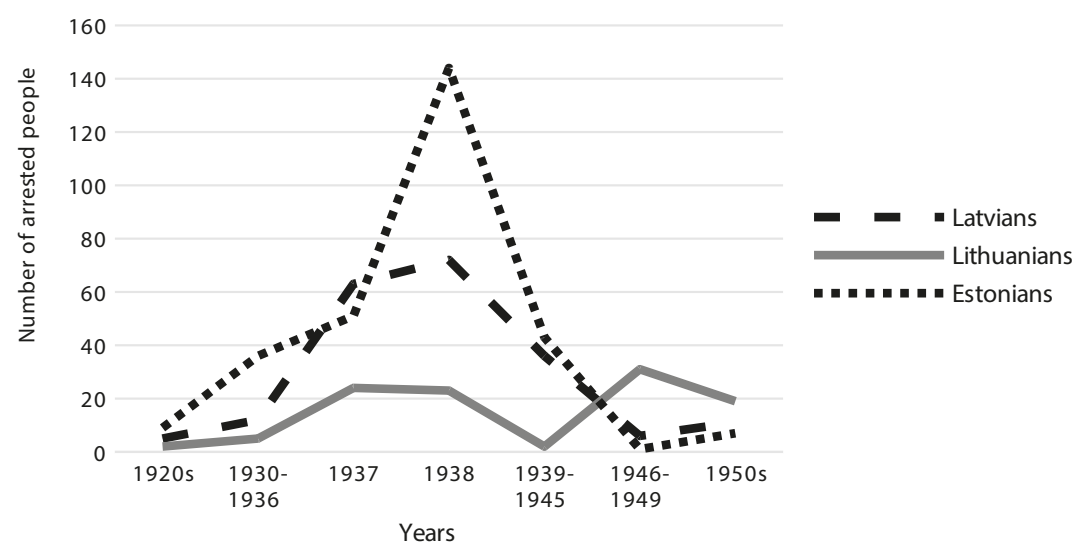

Graph 1. The dynamics of the arrests of the Estonians, Latvians and Lithuanians in Kazakhstan in the 1920s-1950s

As the graph below shows, the peak of arrests among all three national minorities occurred during the years of the Great Terror (1936-38).

Most often, charges were filed under the following sections of Article 58 of the Criminal Code of the RSFSR:

- 58-1a: Treason.

- 58-6: Espionage.

- 58-10: Propaganda or agitation, calling for overthrowing, undermining or weakening the Soviet state.

- 58-11: Any kind of organisational activity aimed at preparing or committing counter-revolutionary crimes.

These four sections account for more than $90 \%$ of all charges. Often, charges were brought under several articles at once, the most frequent being a combination of sections 6,10 and 11 .

On 15 August 1937, Nikolai Ezhov signed NKVD Order No. 00486 'On the repression of wives and the placement of children of convicted traitors to the motherland', according to which the wives of persons convicted for espionage and treason were arrested. The fate of the children, siblings and parents of the convict was determined by the heads of NKVD bodies at the republic and regional levels. Thus, a new category of repressed persons appeared: ChSIR, a member of the family of a traitor to the motherland. No trials were conducted for them; according to the NKVD order, the sentence was 'at least five to eight years'. In December of the same year, the Akmola camp for wives of traitors to the motherland was established 
under the administration of the Karlag camp. Over the years, it appears in official documents as village no. 26, the Akmola special department of the Karaganda labour camp, and the seventeenth Akmola department of Karlag, but the prisoners themselves called it ALZhIR. About eight thousand women served their sentences in ALZhIR, and over eighteen thousand passed through it. The number of women of Latvian, Lithuanian and Estonian nationality is presented in the table below. From the table we can see that 136 women from the Baltic states were in ALZhIR in different years. ${ }^{66}$

Table 1: Number of Baltic women imprisoned in ALZhIR

\begin{tabular}{|l|l|}
\hline Nationality & Quantity (people) \\
\hline Latvians & 101 \\
\hline Lithuanians & 14 \\
\hline Estonians & 21 \\
\hline
\end{tabular}

During the Second World War, Estonians living in Kazakhstan were called to the front. Many of them served in the Estonian national military formations (the $7^{\text {th }}$ and $249^{\text {th }}$ Estonian Rifle Divisions) including D. M. Aas, M. A. Annum, O. K. Vaks, I. I. Valdt, E. A. Valter, and others. The total number of Estonians from Kazakhstan who participated in the war has not been established. However, thanks to the projects Podvig naroda and Pamyat naroda, we have now identified about eighty-nine Estonians in Kazakhstan who took part in the Second World War and were awarded with distinction. ${ }^{67}$

The all-Union censuses of 1959 and 1970 noted an increase in the number of Estonians in Kazakhstan: 3,683 and 4,083 people, respectively. ${ }^{68}$ The following decades consistently show a decline in the number of Estonians in Kazakhstan: in 1989 their number was 3,329 people, but ten years later, there were only 1,819 Estonians. ${ }^{69}$ The main reasons for the decline in numbers can be identified as a natural decline due to their low birth rate and the migration of Estonians from Kazakhstan to Estonia in the late 1980s and early 1990 .

Today, Estonians are the smallest of the Baltic minorities in Kazakhstan. The 2009 census of Kazakhstan also recorded a decline by one half in the

\footnotetext{
66 'ALZhIR' <https://museum-alzhir.kz/ru/o-muzee/statistika> [accessed 1 May 2019].

67 'Podvig naroda'; 'Pamyat' naroda'.

68 Itogi Vsesoyuznoy Perepisi Naseleniya 1979 g. (Moscow, 1990), $\mathrm{x}$.

69 Nacionalnyj sostav, veroispovedanie i vladenie jazykami v Respublike Kazahstan, 4. $<$ https://stat.gov.kz/census/national/2009/general> [accessed 25 May 2020].
} 
number of Estonians from 1,819 in 1999 to 986 in 2009. In the future, the number will continue to decline as a result of natural loss $(28 \%$ of Estonians in Kazakhstan are people over the age of 6o). ${ }^{70}$ In the latter half of the twentieth century, the process of repatriation of Estonians can be observed, but it did not become widespread.

In 1995, an Estonian cultural centre was registered in Almaty, Jaan Lodi became its first chairman. Now it is headed by Nina Dosaeva, but the cultural centre does not conduct any active activities. In 2017, Gennady Pussep ${ }^{71}$ initiated the creation of an Estonian house-museum in UstKamenogorsk. However, due to lack of funding, this project has not yet been implemented. ${ }^{72}$

\section{Latvians}

Latvians first appeared in the territory of Kazakhstan at the end of the nineteenth century. According to the First General Census of the Russian Empire (1897), 322 Latvians lived in the territory of modern Kazakhstan. ${ }^{73}$ Their distribution throughout Kazakhstan was uneven; 218 of them lived in the Kokchetav district of Akmola province. ${ }^{74}$ It was not possible to identify settlements with a high concentration of Latvian immigrants from the available source materials.

In subsequent years, as a result of the active resettlement policy of tsarism, the number of Latvians in Kazakhstan increased. ${ }^{75}$ Analysis of the collection of data shows that among the settlers, immigrants from the counties of Wenden and Wolmar in the province of Livland predominated.

\footnotetext{
70 Nacionalnyj sostav, veroispovedanie i vladenie jazykami v Respublike Kazahstan, 4. 71 Over many years of living in a Russian-speaking environment, many Estonian surnames have changed their original spelling. The surname Puusepp, in this case, is a prime example.

72 Galina Vologodskaya, 'Estonskiy dom zhdet pereyezda', Kazakhstanskaya pravda (Almaty, 25 April 2017) <http://www.m.kazpravda.kz/fresh/view/estonskii-dom-zhdetpereezda/> [accessed 1 January 2020]; Gennady Pussep, interview, 2019. The transcript of the interview is at the disposal of the author.

73 Trojnickij, Pervaya Vseobshchaya perepis' naseleniya Rossiyskoy imperii $1897 \mathrm{~g}$., LXXXI-LXXXVIII.

74 Nationality was determined according to the chosen native language in the census of 1897. It is also worth noting that we have excluded the following regions from our calculations since they are not part of modern-day Kazakhstan: from Akmola province: Omsk District (Russia); from Syr-Darya province: Tashkent District; and the Amu-Darya Department (Uzbekistan).

75 Vsesoyuznaya perepis' naseleniya 1926g. (Moscow: izdatel'stvo TSSU SSSR, 1928), VIII KAZASSR, KIRGIZSKAYA ASSR.
} 
Almost all Latvian immigrants settled in German, Estonian and nationally mixed settlements.

Communist Party policy influenced the number of Latvians in Kazakhstan in the 1920s, when central authorities sent Latvians who were loyal to the Party to fill significant economic and political posts. Analysis of the data collection shows that among the Latvians, natives of Riga with higher and secondary education prevailed. As a result, the number of Latvians in Kazakhstan increased to 1,101 people in 1926. Approximately half of them lived in the cities of the republic. The rural Latvian population was concentrated in two regions of Akmola province (the Makinsk and Schuchinsk volosts of Kokchetav District) and Semipalatinsk province (Zyryanovsky District). ${ }^{76}$

A distinctive feature of the history of the Latvian diaspora in Kazakhstan is the active participation of Latvians in the establishment of the Soviet state and their activities in public service at various levels. For example, in the short period from March to June of 1922, Petr Zhurevsky (1894-1963) was chairman of the State Planning Commission of the Kazakh ASSR. Later the same post was taken by another native of Latvia, August Podnek (1895-?). He was also the deputy chairman of the Council of People's Commissars of the Kazakh ASSR. Jan Greenberg (1897-?) served from February of 1931 to July of 1932 as Deputy Commissar of Justice and Assistant Prosecutor of the Kazakh ASSR. In the same period, another Latvian, Andrei Fekter (1892-1974), was the chairman of the Kyrgyz (Kazakh) Regional Control Commission of the CPSU(b), as well as the People's Commissar of the Workers' and Peasants Inspection of the Kazakh ASSR. Albert Vitolin (1902-?) was the First Deputy People's Commissar of the State Farms of the Kazakh SSR from August of 1937 to June of $1938 .{ }^{77}$

From 1920 to 1922, Petr Struppe worked as Deputy Commissar of Internal Affairs (1889-1937). Over the years (1920-41), the clerks of the OGPU/ NKVD in Kazakhstan were Arkady Wiedeman, Karl Inte, Petr Perkon (Western Kazakhstan region), Aleksandra Zavarzina (East Kazakhstan region), Volfred Braun and Boris Vul (Almaty region), Aleksandr Chembak (Karaganda region). According to the 'Certificate of distribution (arrangement) of Western communists by branches of the national economy of the Kazakh SSR' for 1937, thirteen Latvians worked in the NKVD. ${ }^{78}$

\footnotetext{
76 Vsesoyuznaya perepis' naseleniya 1926g., VIII KAzASSR, KIRGIZSKAYA ASSR.

77 Zhakypov and Zulkasheva, Narkomy Kazakhstana.

78 'Nomenklaturnyye kadry Sovetskogo Kazakhstana'; 'Otkrytyy spisok'.
} 
One of the leaders of non-ferrous metallurgy in the early Soviet years was the Latvian Rudolf Ansovich Dreiman (1887-1942). In 1921 he was appointed manager of the Ridder Mining Enterprise (Ridder, East Kazakhstan), where his main task was to rebuild the company and organise its activities. ${ }^{79}$ Five years later, R. Dreiman was transferred to Karsakpay (Central Kazakhstan), where, together with the famous Kazakh geologist Kuanysh Satpayev, he took part in the establishment of the Karsakpay copper smelting plant, which became the basis for the creation of the large Zhezkazgan industrial hub. ${ }^{80}$

Analysis of resource data in Otkrytyy spisok shows that despite active participation in the construction of the Soviet state, many of the above were repressed in the 1930s: V. Braun, A. Wiedemann, A. Vitolin, K. Greenblat, R. Dreiman, P. Perkonen, A. Podnek, P. Struppe, A. Chembak.

Ordinary Latvians living in Kazakhstan were also repressed. Our collection of personal data contains 214 people of Latvian nationality who were repressed. Analysis of the collection shows that the social status of the majority of the repressed was that of employees and hired workers. The first arrests occurred in the beginning of the 1920 and continued with varying degrees of intensity until the late 1950s. The peak of arrests was in 1937 and 1938. In these two years, 135 Latvians were arrested. Out of 214 arrested Latvians, the sentence of capital punishment (by shooting) was handed down to ninety-five people, and another seventy-two were sentenced to six to ten years of hard labour. In twenty instances, the case was dismissed, most often with the wording 'for lack of evidence of corpus delicti'.

Due to the deportations of 1941 and 1949, the number of Latvians in Kazakhstan increased slightly. In 1939 there were 3,612 Latvians, but by 1959 there were 4,588 . Twenty years later, the number of the Latvian diaspora was approximately at the same level - 4,300 people. The census of 1989 showed a sharp decline in the numbers: over the ten-year intercensal period, the Latvian population declined by 1,037 people. ${ }^{81}$ In subsequent years, the decline of the Latvian population of Kazakhstan continued as

\footnotetext{
79 One of the streets in Ridder is named Rudolf Dreiman, and the archive materials devoted to Dreiman's activity are stored in the Ridder branch of the state archive of the East Kazakhstan region (collection 63, Op. 3).

80 'Dreiman Rudolf Ansovich'", State archive of the East Kazakhstan region and its branches $<$ http://e-arhiv.vko.gov.kz/ru/Page/Index/1776> [accessed 14 December 2019].

81 Naseleniye Kazakhstana po Vsesoyuznoy perepisi 1939 goda., 5 vols. (Almaty: Arys, 2009), I; Nacionalnyj sostav, veroispovedanie i vladenie jazykami v Respublike Kazahstan, 4 .
} 
a result of migration to Latvia, natural decline, and assimilation into the local population.

Due to the small number of the Latvian population, no Latvian cultural centres have been created in Kazakhstan. Nevertheless, it should be noted that Latvia and Kazakhstan have closer cultural ties (in comparison with Estonia and Lithuania). So in 2004, during the state visit of Latvia's President Vaira Vỉke-Freiberga to Kazakhstan, 227 archive files of repressed Latvians were given to her. ${ }^{82}$ Also, in 2013, a monument to repressed Latvians was unveiled at the Spassky Memorial Complex. ${ }^{83}$

\section{Lithuanians}

The Lithuanian diaspora of Kazakhstan differs considerably from the Latvian and Estonian diasporas. According to the 1897 census, the number of Lithuanians in Kazakhstan was only 20 people, and $75 \%$ of them lived in cities ( 15 people). ${ }^{84}$ The Russian policy of peasant resettlement at the beginning of the twentieth century led to a small increase in the number of Lithuanians in Kazakhstan. It should be noted that there were no separate Lithuanian settlements in Kazakhstan. According to data from the first Soviet census of 1926, out of 312 Lithuanians, nearly half lived in the cities of the Kazakh ASSR. By 1939, the number of Lithuanians in Kazakhstan, though it had grown, did not even reach one thousand (818 people). ${ }^{85}$

A sharp increase in the Lithuanian diaspora was related to the deportation of Lithuanians in 1941 and 1949. The census of 1959 counted 12,132 people of Lithuanian nationality. ${ }^{86}$

Lithuanians, as well as representatives of other nationalities living in Kazakhstan, were subjected to repressions. According to our calculations, based on analysis of Otkrytyy spisok data in the period from 1920 to 1940, fifty-six Lithuanians were arrested, and the peak of arrests occurred in the years 1937-38. Unlike the repressions against Latvians and Estonians,

82 Yevgeniy Kononovich, 'Tranzit na vstrechnykh kursakh. Kazakhstan i Latviya rasshiryayut potentsial partnerstva', Kazakhstanskaya pravda (Almaty, 9 October 2004), 1.

83 Natalya Ryzhkova, 'Postizheniye Obshchey Istorii', Kazakhstanskaya Pravda (Almaty, 13 June 2013) <https://www.kazpravda.kz/archives/view/54930?print=yes >.

84 Trojnickij, Pervaya Vseobshchaya perepis' naseleniya Rossiyskoy imperii $1897 \mathrm{~g}$., LXXXI-LXXXVIII.

85 Vsesoyuznaya perepis' naseleniya 1926g., VIII KAzASSR, KIRGIZSKAYA ASSR; Naseleniye Kazakhstana po Vsesoyuznoy perepisi 1939 goda., I.

86 Smailov, Nacionalnyj sostav. Itogi perepisi 2009g., 4. 
the repressions against Lithuanians continued up to the end of the 1950 . During the years 1941-59, the NKVD arrested a total of 50 Lithuanians. ${ }^{87}$ The number of arrests can be determined from the materials of archival cases. A striking example is the complaint to the Supreme Court of the USSR from the arrested Lithuanian Kazimir Nenis (born 1895). In it he says:

I was arrested for the allegation that I was engaged in espionage, obviously for the simple reason that I was Lithuanian, and had correspondence in Lithuanian with my family, sister and brothers living in Lithuania. My surname, name and patronym, obviously, were suspicious too (and the investigation convinced me of that). ${ }^{88}$

As a result, Kazimir Nenis was sentenced in 1938 to ten years of hard labour with subsequent disfranchisement for five years, but in 1939 the sentence was cancelled by the Judicial Board on Criminal Cases of the Supreme Court of the USSR. ${ }^{89}$

While analysing the personal data collection, our attention was drawn to the wave of arrests of women of Lithuanian nationality, which swept the Guryev area (today the Atyrau region of Western Kazakhstan) in 1941-42. We identified sixteen people who were arrested and convicted within one year (between August of 1941 and August of 1942). In addition to nationality, those arrested had a great deal in common: almost all of them were born in Lithuania, had a primary education, and worked in lower positions (diggers, cleaners, oil field workers, etc.). The first arrests were carried out on 15 August 1941 in Guryev. The Guryev regional prosecutor's office arrested three people at once: Stasya Masyulyunayte, Zofia Stepanovichute and Elena Devetuvna. The women were charged with 'sabotage' under article 58, section 14. Their trial lasted one day on 20 September 1941. E. Devetuvna was sentenced to four years of hard labour but the sentences of the others are unknown. ${ }^{90}$

The subsequent wave of arrests took place on 9 September 1941 at the Makat oil enterprise (Makat District, Atyrau region). The local Makat regional department of the NKVD arrested Apolonia Kuntsene-Samulite, Elena Kuchaitie, Vanda Pabedinishkayte, and Valeria Yakubaytit. Charges were brought against them according to Section 10 of the same Article 58

\footnotetext{
87 'Otkrytyy spisok'.

88 M. Koygeldiyev, V. Polulyakh, and Sh. Tleubayev, Krasnyy Terror: Iz Istorii Politicheskikh Repressiy v Kazahstane (Almaty: Alash baspasy, 2013).

89 Koygeldiyev, Polulyakh, and Tleubayev, Krasnyy terror.

90 'S.S. Masyulyunayte, Z.A. Stepanovichute, E.K. Devetuvna', Otkrytyy spisok $<$ https:// ru.openlist.wiki> [accessed 1 May 2019].
} 
('Propaganda and agitation'). The trial of all of them also took place in a single day on 16 January 1942. All four were sentenced to from seven to ten years of hard labour. ${ }^{11}$

Arrests of Lithuanian women in the Atyrau region continued into the autumn of 1941, and in the Makat and Inder districts and in Guryev they continued into 1942. The arrested women were charged according to Article 58-10 and the courts pronounced sentences of ten years of hard labour. Perhaps this course of events was connected to the fact that in the first years of the war, the Guryev area was in a unique situation due to the fact that a number of oil enterprises had been evacuated. Moreover, the forced construction of oil refineries and the import of oil took place to provide for the front. Unfortunately, it is impossible to know the basis for the charges or the specifics of the crimes due to limited access to the cases of the repressed. ${ }^{92}$

In 1954, the development of 'virgin lands' began in Kazakhstan, which demanded a large amount of resources, including human labour. People started coming to Kazakhstan from all regions of the USSR to plough the virgin lands. The largest number of migrants came from the Ukrainian and Belarusian SSRs. Lithuania was the only one of the Baltic states to contribute a large number of peasants. The regions that received most of the flow of new migrants were the Karaganda, North Kazakhstan and Akmola (at that time renamed Tselinograd) oblasts. Overall, the 'Tarankulsky' sovkhoz (state farm) in the North Kazakhstan area admitted twenty-one families from Lithuania in 1964, and the 'Petrovka' sovkhoz in the Karaganda region admitted thirty-nine Lithuanian families in $1967 .{ }^{93}$

In 1956, the Lithuanian Yu. Rodzyavichus moved with his family from the city of Prienai to the North Kazakhstan oblast, where he worked at the Molotov agricultural artel, in Priishimsky District. In 1967, I. Lyutkevichus moved from Šiauliai to the Karaganda region with his family, where he began to work as a tractor operator in a sovkhoz named Pushkin in the Ulyanovsk district. Also, the Lithuanians Indryam Iozo, Kazimir

\footnotetext{
91 'A. Kuntsene-Samulite, E. B. Kuchaitie, V. U. Pabedinishkayte, V. U. Yakubaytit', Otkrytyy spisok <https://ru.openlist.wiki> [accessed 1 May 2019].

92 The archive of the Committee of National Security of Kazakhstan provides documents on cases concerning victims of political repressions only to relatives and in limited amounts.

$93 \quad$ K Nam, v Kazakhstan! (Alma-Ata, 1964), 32; K Nam, v Kazakhstan! (Alma-Ata, 1969), 37.
} 
Belyaukas, Ionas Vaytkus, Alekso Adolfas, Ona Mitskene moved to Kazakhstan in different years to help with the development of virgin soil. ${ }^{94}$

Thus, as a result of Stalin's deportations and the development of virgin lands, the number of Lithuanians in Kazakhstan reached its maximum level: the 1970 census recorded 14,194 people of Lithuanian nationality. ${ }^{95}$

In the next three decades, the Lithuanian diaspora decreased as a result of international migration and natural decline. According to the 2009 census of Kazakhstan, there were 4,925 Lithuanians living in the republic. ${ }^{96}$ Today, it is the largest diaspora of the Baltic republics. The largest number of Lithuanians live in the Karaganda region. A Lithuanian cultural centre was opened there in 2003 at the initiative of Lithuanians living in Kazakhstan, and with the assistance of the Embassy of the Republic of Lithuania in Kazakhstan. A house museum was also opened in 2015. The centre offers courses in the Lithuanian language, as well as in history and culture. Holidays and exhibitions are organised as well. ${ }^{97}$

\section{Conclusion}

The aim of this study is to show the ways in which the Estonian diaspora in Kazakhstan took shape in comparison with other Baltic diasporas (Latvians and Lithuanians).

The narrow source base determined the main research tool: the creation of a collection of personal data of all the Latvians, Lithuanians and Estonians who had ever lived in Kazakhstan. Work continues on the collection and it is continually being supplemented with new biographies. A quantitative and qualitative analysis of the personal data has allowed us to trace the main stages of the formation of the Latvian, Lithuanian and Estonian diasporas in Kazakhstan. This study has shown that despite their common history, first in the Russian Empire, and then in the Soviet Union, the national minorities took shape in different ways. In summary, Latvians and Estonians appeared in Kazakhstan at the end of the nineteenth century as a result of peasant resettlement. The Latvians did not form independent

\footnotetext{
$94 \quad$ Pereselyaytes' $k$ Nam $v$ Severnyy Kazakhstan! (Alma-Ata, 1957); Pereselyaytes' $v$ Severnyy Kazakhstan (Alma-Ata: Kazakhstan, 1966); K Nam v Severnyy Kazakhstan (Alma-Ata: Kaynar, 1966); K Nam, v Kazakhstan!; K Nam, v Kazakhstan!

95 Smailov, Nacionalnyj sostav. Itogi perepisi 2009g., 4-5.

96 Nacionalnyj sostav, veroispovedanie i vladenie jazykami $v$ Respublike Kazahstan, 4.

97 Menin Kazakstanym. Spravochnik o deyatel'nosti etnokul'turnykh ob'yedineniy Kazakhstana (Astana, 2015) <https://assembly.kz/sites/default/files/menin kazakstanim_m_O_1.pdf> [accessed 12 December 2019], 55 .
} 
settlements and lived in Russian, German and Estonian villages, as well as in cities. Estonians formed several independent settlements (Petrovskoe and Liflyandskoe in Akmola province, Verhnyaya Elovka in Semipalatinsk province). The number of Lithuanians in Kazakhstan before the 1940 S was very small. Lithuanians came to Kazakhstan as a result of the Stalinist deportations of 1941 and 1949, which increased the numbers of Lithuanians dramatically.

In the 1930s, at least 602 people of Estonian, Latvian and Lithuanian nationality were repressed in Kazakhstan. This represents approximately $16 \%$ of the total Baltic diaspora. In addition, Kazakhstan became a place of expulsion and hard labour sentences from other regions of the Soviet Union. The proportion of Estonians, Latvians and Lithuanians among the prisoners is still an open question. Along with representatives of other nationalities, Estonians, Latvians and Lithuanians of Kazakhstan took part in the battles of World War II in the ranks of the Red Army. We have identified more than one hundred people decorated for their military service. This work continues.

In the early 1970s, the size of the Estonian, Latvian and Lithuanian diasporas reached its peak and amounted to twenty-two thousand people. As a result of the softening of the political regime in the last years of the Soviet Union, many of the repressed persons and deportees gained the right to return home. The migration outflow continued into the 1990 os. Another important factor in reducing the number of Baltic minorities has been natural decline. As a result, by 2009 , the total number of Estonian, Latvian and Lithuanian diasporas had decreased by a factor of 3.2. To date, the Lithuanian diaspora remains the largest of the Baltic nations. They have created a national cultural centre in the Karaganda region, where people can learn the Lithuanian language and culture.

This article is the first attempt to provide a general description of the history of the Estonian, Latvian and Lithuanian diasporas in Kazakhstan. It poses a number of future tasks and research questions. For example, what was the economic situation of Estonian peasants on the eve of the 1917 revolution? Is it true that Estonian farms not only became economically more robust but, according to popular belief, also became prosperous? A detailed analysis of not only Estonian but also neighbouring Russian and German settlements, according to the 1917 agricultural census, can provide an answer to this question. The contribution of Latvians sent to Kazakhstan by the Communist Party in the 1920s to restore the economy of the region remains unexplored. What was the fate of the Lithuanians deported 


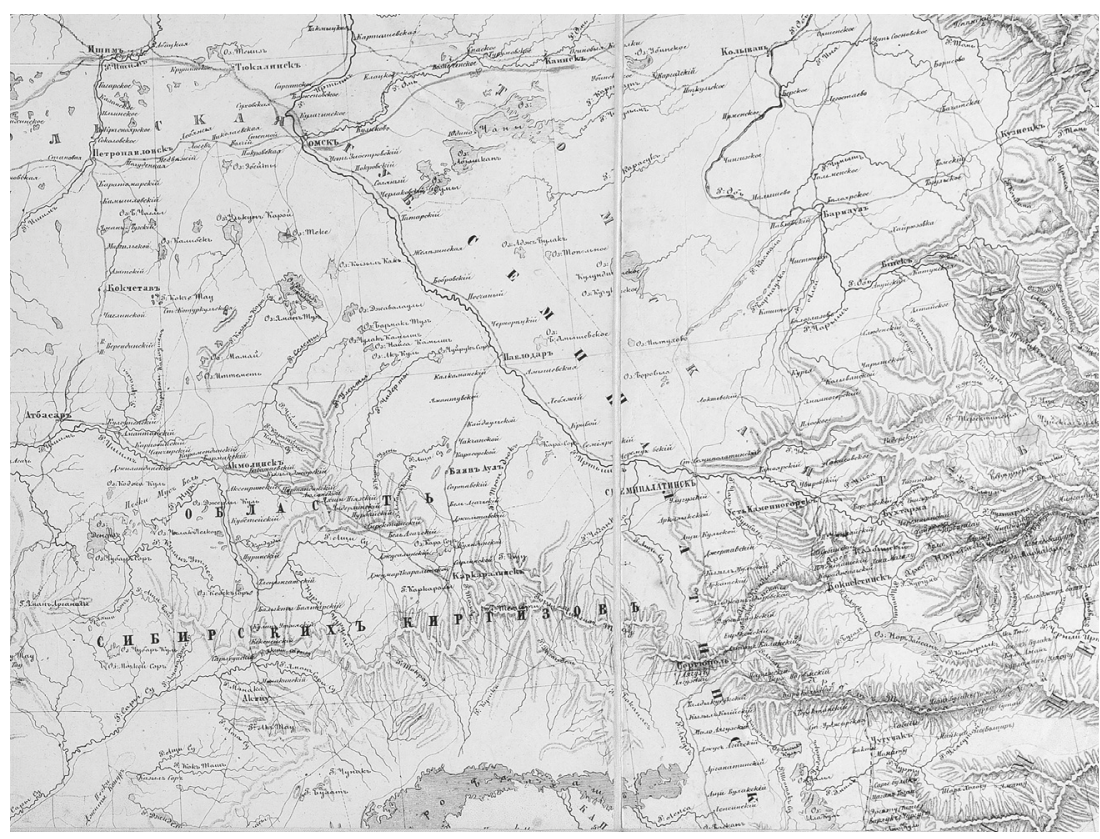

Figure 1. Area where larger Estonian settlements in Kazakhstan were situated: Estonian settlements (Petrovskoe, Liflyandskoe and Verhnyaya and Nizhnyaya Elovka), and mixed ethnic villages inhabited by Estonians (Sopetovo, Nemeckoe, Bodaj-Kuduk and Gerasimovka). Detail of a larger map. Estonian Historical Museum, Eesti Ajaloomuuseum SA, AMD117 1-325

to Kazakhstan? And, of course, it is essential to study the current situation of the Estonian, Latvian and Lithuanian diasporas in Kazakhstan. In this context, attention should be paid not only to demographic indicators but also to issues of national identity and the preservation of national cultures.

KEYwORDs: Kazakhstan; diaspora; migration; the Baltic states

MariYa Oinas is a PhD student at the Institute of History and Archaeology, University of Tartu.*

\footnotetext{
* Correspondence: Institute of History and Archaeology, University of Tartu, Jakobi 2, 51005 Tartu, Estonia.E-mail: mariya.oinas@ut.ee
} 
KoкKUvõte: Biograafiline teave ajalooallikana eestlaste ja teiste baltlaste Kasahstani diasporaa näitel

Kõige viimase, 2009. aasta rahvaloenduse järgi elab Kasahstanis 16 miljonit elanikku, kellest $40 \%$ ei ole kasahhid. Nende hulgas on pea 130 rahvuse ja etnilise grupi esindajad. Mitmerahvuselise Kasahstani tekkimisel on keeruline kahe sajandi pikkune ajalugu. Iga etnilise grupi ajalugu Kasahstanis on unikaalne ja tihti traagiline.

Osa diasporaagruppide kujunemisele Kasahstanis on pööratud väga vähe tähelepanu, nende hulgas on ka sealsed eesti, läti ja leedu vähemused. 2009. aasta rahvaloendus registreeris riigis umbes 7000 nende rahvuste esindajat, mis on vähem kui o,1\% kogu elanikkonnast. See on üks võtmepõhjusi, miks on nende kohta nii vähe teavet. Teiseks põhjuseks on allikate vähesus. Kuna tänaste Balti riikide aladelt tulnud migrantide arv on alati olnud väike võrreldes teiste rahvustega (venelased, ukrainlased, valgevenelased, sakslased, poolakad jne), ei kajastu nende arv üldisemates statistilistes ülevaadetes, arhiivimaterjalides ega käsitlustes. Nii mainiti 19. sajandi lópu ja 20. sajandi alguse talurahva ümberasumise ajal eestlasi ja lätlasi "saksa populatsiooni" osana. Stalini küüditamiste käigus varjutasid eestlaste, lätlaste ja leedulaste arve palju suuremad sakslaste, poolakate ja valgevenelaste arvud.

Eesti, läti ja leedu diasporaa ajalugu Kasahstanis on huvitav ka sellepärast, et see on osa nende gruppide päritolumaade ajaloost. Ühest küljest on oluline teada, kuhu ja miks tänaste Balti riikide elanikud lahkusid või ümber asustati. Teisest küljest on isegi väikseimad diasporaagrupid osa Kasahstani elanikkonnast. Neil on oma ajalugu, mis on kui pusletükk, mis kuulub selle riigi 2o. sajandi ajaloo tervikpilti.

Käesoleva uurimuse eesmärk on anda üldine ajalooline ülevaade eesti, läti ja leedu diasporaade tekkimisest Kasahstanis 19. sajandi lópust kuni 20. sajandi lõpuni, et tõmmata uurijate tähelepanu sellele temaatikale. Kitsas allikaline baas määras uurimismeetodi: andmekogu loomine Kasahstanis elanud eestlastest, lätlastest ja leedulastest. Täna koosneb see 1113 biograafiast, millest 577 on eestlaste, 374 lätlaste ja 162 leedulaste elulood.

Teave iga isiku kohta on kogutud viit peamist tüüpi allikatest: monograafiad ja mälestused, publitseeritud ja publitseerimata arhiivimaterjalid, Kasahstani ajakirjandus ja kodu-uurimused, biograafilised käsiraamatud ja intervjuud ning võrguandmebaasid. Isikute kohta kogutud teabe kvantitatiivne ja kvalitatiivne analüüs aitas välja selgitada Kasahstani eesti, läti ja leedu diasporaade tekkimise põhilised staadiumid. Selgub, et vaatamata 
päritolurahvaste sarnasele ajaloole Vene impeeriumis ja hiljem Nõukogude Liidu koosesisus arenesid rahvuslikud vähemused erinevalt.

Kokkuvõttes võib öelda, et lätlased ja eestlased ilmusid Kasahstani 19. sajandi lõpul talupoegade ümberasumise tulemusena. Esimene Eesti asundus Kasahstanis asutati 1893. aastal Novočerkasski vallas Akmola maakonnas Akmola provintsis ja sai nimeks Petrovskoe. Selle rajasid Liivimaalt Võru maakonnast pärit talupojad. 1905. aastal asutati Akmola maakonnas Shokai asundus, mis sai oma nime samanimeliste allikate järgi. Eestlased moodustasid seal 1906. aastal (või mõnede allikate järgi 1907. aastal) Liflyandskoe asunduse. Lisaks Kesk-Kasahstanile kolisid eestlased ka Ida-Kasahstani. Aastatel 1905-06 rajati Zaysani piirkonda Hiina piiril Markakoli järve ääres mitu asundust. 1908. aastal saabusid sinna eesti ümberasujad ning asutasid samuti mitu asulat. Hiljem moodustati neist Ülem-Elovka ja Alam-Elovka külad.

Lätlased ei moodustanud eraldi asulaid ja elasid vene, saksa ja eesti külades ning linnades. Esimese Vene impeeriumi rahvaloenduse järgi 1897. aastal elas tänase Kasahstani aladel 322 lätlast. 1926. aastaks oli lätlaste arv kasvanud 1101 isikuni. Elanikkond suurenes tänu Stolõpini maareformidele ja Nõukogude rahvuspoliitikale, millega seoses jõudsid lätlased tähtsatele kohtadele parteis ja ettevõtetes. Läti diasporaad eristas lätlaste osa Nõukogude riigi ülesehitamisel ja nende tegevus avalikus sfääris erinevatel tasanditel.

Leedu diasporaa erineb oluliselt läti ja eesti diasporaast. 1897. aasta rahvaloenduse järgi oli Kasahstanis vaid 20 leedulast. Vene impeeriumi ümberasumispoliitika 20. sajandi alguses viis siiski mõningase leedulaste arvu suurenemiseni.

Eesti ja Nõukogude Vene vahel sõlmitud Tartu rahulepingu järgi said Eestist pärit Venemaal elavad isikud taotleda Eesti kodakondsust ja Venemaalt lahkuda. Eestlastel, kes elasid tänase Kasahstani territooriumil, lubati taotleda Eesti kodakondsust Omski kontroll-opteerimiskomisjoni kaudu. Tänaseks olen leidnud 81 Kasahstani eestlaste taotlust. Koos pereliikmetega soovis Eesti kodakondsust saada 251 isikut. Eesti kodakondsuse taotluste ja tegelike optantide täpne arv on hetkel veel teadmata.

1930. aastatel represseeriti Kasahstanis vähemalt 602 eesti, läti ja leedu rahvusest isikut, mis moodustab umbes $16 \%$ tollasest balti diasporaast. Lisaks sai Kasahstanist küüditamiste ja sunnitöölaagritesse saadetute sihtkoht Nõukogude Liidus. Eesti, läti ja leedu vangide täpne arv ja osakaal on samuti hetkel veel väljaselgitamisel. 
1941. ja 1949. aasta küüditamiste tulemustena suurenes eestlaste ja lätlaste arv vaid veidi, samas kui leedulaste arv kasvas küüditamiste järel järsult. 1959. aasta rahvaloenduse järgi oli Kasahstanis 12132 leedulast.

Analüüsides isikute andmekogu äratas tähelepanu arreteerimiste laine, mis tabas aastatel 1941-42 Gurjevi piirkonna (tänane Atõrau Lääne-Kasahstanis) leedu rahvusest naisi. Tuvastasin 16 isikut, kes arreteeriti ja kellele mõisteti karistus ühe aasta jooksul, augustist 1941 augustini 1942.

Koos teiste rahvuste esindajatega võtsid Kasahstani eestlased, lätlased ja leedulased Punaarmee koosseisus osa Teise maailmasõja lahingutest. Olen tänaseks leidnud enam kui 100 isikut, kes on saanud oma teenistuse eest autasu, kuid uurimistöö jätkub ka sel alal.

1970. aastate alguses oli Kasahstani eesti, läti ja leedu diasporaa arvuline tippaeg, kokku 20 ooo isikut. Poliitilise režiimi pehmenemise tulemusena Nõukogude Liidu viimastel aastatel said mitmed represseeritud õiguse koju tagasi pöörduda, mille tulemusel balti diasporaa vähenes. Nende väljaränne toimus 1990. aastateni. Teine oluline faktor on elanikkonna loomulik vähenemine. 2009. aastaks oli balti diasporaa vähenenud 3,2 korda. Täna on leedu diasporaa balti vähemusrühmadest suurim. Nad on loonud rahvusliku kultuurikeskuse Karaganda piirkonnas, kus on võimalik õppida leedu keelt ja saada teavet leedu kultuuri kohta.

Käesolev artikkel on esimene katse kirjeldada eesti, läti ja leedu diasporaa ajalugu ning see esitab mitmeid küsimusi edasiseks uurimiseks: miks otsustasid eestlased 20-30 aastat pärast ümberasumist Eestisse tagasi minna? Mitmel eestlasel õnnestus saada Eesti kodakondsus ning reaalselt Eestisse tagasi jõuda? Kui paljud eestlased, lätlased ja leedulased sunniti Kasahstani välja rändama 1930. ja 1940. aastatel? Milline oli nende edasine staatus? Kas nad jäid paigale või kolisid 1970. ja 1980. aastatel kodumaale tagasi? Eestlaste, lätlaste ja leedulaste osa uudismaade ülesharimise kampaanias on samuti vähe uuritud. 